\title{
University and College Differences in the Returns to Education in Japan and the Netherlands
}

\author{
Citation for published version (APA):
}

van der Velden, R. K. W., van de Loo, P., \& Meng, C. M. (2007). University and College Differences in the Returns to Education in Japan and the Netherlands. In J. Allen, Y. Ynenaga, R. V. D. Velden, \& K. Yoshimoto (Eds.), Competencies, Higher Education and Career in Japan and the Netherlands Kluwer Academic Publishers. Higher Education Dynamics https://doi.org/10.1007/978-1-4020-6044-1_4

Document status and date:

Published: 01/01/2007

DOI:

10.1007/978-1-4020-6044-1_4

Document Version:

Publisher's PDF, also known as Version of record

\section{Please check the document version of this publication:}

- A submitted manuscript is the version of the article upon submission and before peer-review. There can be important differences between the submitted version and the official published version of record. People interested in the research are advised to contact the author for the final version of the publication, or visit the DOI to the publisher's website.

- The final author version and the galley proof are versions of the publication after peer review.

- The final published version features the final layout of the paper including the volume, issue and page numbers.

Link to publication

\footnotetext{
General rights rights.

- You may freely distribute the URL identifying the publication in the public portal. please follow below link for the End User Agreement:

www.umlib.nl/taverne-license

Take down policy

If you believe that this document breaches copyright please contact us at:

repository@maastrichtuniversity.nl

providing details and we will investigate your claim.
}

Copyright and moral rights for the publications made accessible in the public portal are retained by the authors and/or other copyright owners and it is a condition of accessing publications that users recognise and abide by the legal requirements associated with these

- Users may download and print one copy of any publication from the public portal for the purpose of private study or research.

- You may not further distribute the material or use it for any profit-making activity or commercial gain

If the publication is distributed under the terms of Article $25 \mathrm{fa}$ of the Dutch Copyright Act, indicated by the "Taverne" license above, 


\title{
Chapter 4
}

\section{UNIVERSITY AND COLLEGE DIFFERENCES IN THE RETURNS TO EDUCATION IN JAPAN AND THE NETHERLANDS}

\author{
Rolf van der Velden*, Peet van de Loo** and Christoph Meng* \\ * University of Maastricht \\ ** Ministry of Transportation
}

\subsection{Introduction}

Since the late sixties and seventies of the last century, labour market researchers have conducted studies on the relationship between school quality and earnings (e.g. Morgan and Sirageldin, 1968; Welch, 1969; Johnson and Stafford, 1973 and Wachtel, 1976). Although these studies indicate a significant positive relationship between school quality (e.g. educational expenditure per capita) and earnings, the results have been called into question. Researchers argued that family background variables affect both educational expenditures and earnings (Card and Krueger, 1992). Other studies, however, showed that college quality effects remain even after controlling for factors like social background, ability, grades and aspirations (Alwin, 1974; Wise, 1975, Trusheim and Crouse, 1981; Rumberger and Thomas, 1993; Card and Krueger, 1996).

In Japan there is a strong awareness of status differences between the individual universities. The educational institute from which a student graduates has a strong impact on the subsequent occupational career. The entrance examinations conducted by the different institutes of higher education serve as a powerful screening device for employers, and recruitment into topmanagement positions is closely related to the elite institutions (Rosenbaum et al., 1990; Ishida et al., 1997). Sakamoto and Powers (1995) refer to the term "examination hell (juken jigoku)" to describe the pressure related to performing well in the entrance examinations in order to gain access to the 
most prestigious universities. Just like the US (Webster, 2001), prestige differences between universities in Japan are largely related to differences in entry selection.

In contrast, the Netherlands has a relatively standardised system of higher education, with only one main institutional difference, between the more academically oriented universities (leading to a masters degree) and institutes of higher vocational education (leading to a bachelors degree). The highest track in secondary education (VWO) gives direct access to a university study, while the second highest track (HAVO) gives direct access to higher vocational education. With the exception of a few specific study programmes, in general no further selection takes place, although some higher education programmes may pose specific requirements regarding the subjects taken in secondary education. Differences between universities or between institutes of higher vocational education are considered to be small. Nevertheless, people have become increasingly aware of quality differences between the institutes. These differences can vary with the study programmes within an institute and relate to quality of the curriculum, teaching staff or study provisions rather than to differences in selection upon entry. Illustrative in this respect is the ranking published annually since 1999 by the Dutch weekly magazine Elsevier. This magazine is an important public information source for educational managers, teachers and students to compare the quality of their institute with others. Research has also shown that Dutch higher education institutes differ significantly in terms of the success of their graduates on the labour market. Bosker et al. (2001) show that there are systematic differences between departments and colleges in higher vocational education in labour market outcomes. These effects remain significant, although small, even after controlling for student characteristics and regional factors, and are mostly due to differences between departments, rather than differences between colleges. Allen et al. (2000) report similar results for differences between universities. Again, these differences are course-specific: some universities fare better with course A, whereas others fare better with course B.

Results from so-called 'effective school' research show estimates of net between-school variation in educational outcomes (controlling for pre-test scores and socio-economic status of students) ranging from $15 \%$ in the industrialised countries to some $25 \%$ in developing countries (e.g. Creemers \& Scheerens, 1994; Scheerens \& Bosker, 1997). It is generally thought that school effects in labour market outcomes will probably be less strong, due to the intervening effects of other factors (see Bosker et al, 2001). However, this need not necessarily be the case if there are strong signalling effects. In general one can say that there are three forces driving the different outcomes between colleges or universities: 
1. Differential selection: universities and colleges may differ in the (self-) selection of students both upon entry and during the course in higher education. Independent of the actual content of the courses, some institutes may simply attract the more able or more motivated students.

2. Differential accumulation of competences: universities and colleges may differ in the cognitive and non-cognitive skills that students acquire during their course. This relates directly to the added value of a university or college and may be caused by differences in course content, teacher-student ratio, study provisions etc.

3. Differences in social network: universities and colleges may differ in the opportunities they offer to their students to use social networks to enter the labour market and further develop their careers (Rosenbaum et al., 1990). These network effects are particularly important in Japan, where employers have long lasting and well established relations with specific institutes of higher education. Employers use the recommendations of professors when considering job applicants, and only the (male) graduates of the 'best' national and private universities receive 'job books' from the 'best' employers. Network effects may also result from the informal ties between alumni of the same university (Ishida et al., 1997).

Although theoretically these factors relate to different mechanisms, it is hard to distinguish them in practice. One obstacle is a lack of adequate control variables that directly reflect these different mechanisms. For example, without proper controls for ability upon entry and competences at the end of the course taken, it is hard to distinguish between the first two mechanisms. Another obstacle is that these mechanisms are not mutually exclusive, but tend to reinforce each other. For example, social networks may only be effective in case of real differences in competences. Finally, the effects may differ during the career. Psacharopoulos (1979) distinguished between the weak and the strong version of the screening hypothesis. The weak version asserts that, due to a lack of direct productivity indicators, employers use educational credentials to infer potential productivity. However, as time progresses 'real productivity' is revealed to them, so that they no longer need such screening devices. In that case, screening effects will be strongest at the beginning of the career (Ishida et al., 1997). If, however, the educational credentials reflect 'real differences' in productivity, the effect will last longer.

Ishida et al. (1997) use personnel data of two large finance and insurance firms in the US and Japan, respectively, to assess the effect of college quality on promotion chances. They find that educational credentials play a powerful role in the Japanese firm and that the effects are strongest at the beginning of the career. They find little support for the strong version of the screening hypothesis. The effects of college quality seem to be related to the superior cognitive and 
non-cognitive competences acquired by graduates at the elite institutions, rather than to the social networks these institutes provide (Ishida et al., 1997).

This chapter extends the empirical evidence on the effects of university and college quality on earnings in a number of ways:

- It uses data from two different cohorts of graduates in Japan and the Netherlands to assess short-term ( 3 years after graduation) and long-term (approximately 8 years after graduation) effects on the career.

- It uses specific information about input characteristics of students as well as self-reports on the level of competences acquired at the time of graduation.

- It uses graduates' reports on the quality of the course undertaken in higher education.

- It uses information about the search channels that graduates used to find their first relevant job.

The chapter focuses on the following four questions:

1. Do institutes of higher education in Japan and the Netherlands vary systematically in the returns to education?

2. Are these university or college effects caused by differences in selection or social composition of the student population, acquired competences during the course, quality of the course taken, or the social network of the institute?

3. In what sense do the results differ between Japan and the Netherlands?

4. In what sense do the results differ between cohorts (three and eight years after graduation)?

\subsection{Modeling Issues}

We use the natural logarithm of gross hourly wages as the dependent variable. The hourly wages are calculated by dividing the gross monthly wages (including earnings from overtime) by the number of contract hours per month. Analyses are performed on all four data sets separately, i.e., the $1994 / 1995$ cohorts in both countries as well as the 1988/1990 cohort in Japan and the 1990/1991 cohort in the Netherlands. In all four cohorts we selected those respondents with working hours in the range of $20-48$, thereby excluding those with only side jobs or biases due to extremely long working hours. Moreover, we left out the upper and lower $0.5 \%$ of the hourly wage distribution to avoid outliers. Furthermore, we selected respondents in the age range $25-40$ for the young cohorts and $27-45$ for the older cohorts.

Assessing the effect of colleges and universities on the returns to education comes down to decomposing the total variance in wages into two parts: the between-institution variance and the within-institution variance, and then relating the between-institution variance to the total ( $=$ between plus within institution) variance in wages. As universities and colleges may differ in 
course composition and courses may differ in labour market prospects, we want to control statistically for the effect of course composition. ${ }^{\prime}$ The data are therefore grouped as a three-level hierarchy with individuals nested in collegecourse combinations and college-course combinations nested in courses. We used random coefficient models (Bryck \& Raudenbush, 1992; Goldstein, 1995; Snijders \& Bosker, 1999) to assess the regression parameters, variance components and residuals. By modelling courses as the first level, we were able to separate out the total effect of between-course variance before assessing the effect of the colleges. Stated differently, the variance between universities and colleges is assessed after taking account of the differences between universities and colleges in course composition.

In the analyses we estimated six different models. In model 1, an empty model is estimated to assess the different variance components before taking any explanatory variables on board.

In model 2 we include 6 dummies to indicate the educational sector of the course taken (Arts \& Humanities is the reference category) and in the case of the Netherlands a dummy indicating the level of higher education ( 1 = university; $0=$ higher vocational education).

In model 3 we control for several input characteristics. Unfortunately we have no information about the individual entrance examination scores or of the grades in secondary education. Instead we used a dummy indicating whether the respondent followed the academic track in secondary education $(1=$ yes, $0=$ no). Furthermore we included gender $(1=$ male, $0=$ female $)$, a dummy indicating whether the respondent's father has followed higher education $(1=$ yes, $0=$ no), and a dummy indicating whether the respondent's mother has followed higher education $(1=$ yes, $0=$ no).

In model 4 we add variables related to the competences that graduates possess at the time of graduation. The survey contains graduates' self-reports on a list of some 35 competence items, in which they had to assess the extent to which they possessed these items at the time of graduation. ${ }^{2}$ To reduce the number of items, we first conducted factor analyses on all four data sets. These analyses revealed, however, that the underlying factor structure was not the same in all four data sets. We therefore decided to reduce the number of competence items by performing an OLS regression analysis with the natural logarithm of hourly wage as the dependent variable and all competence items as predictors. We then selected all those items that showed a significant effect at the $10 \%$ level in the expected direction in any of the four data sets. This resulted in a sub-set of 15 items (all coded in the following range: 1: does not possess at all; 5: possesses to a great extent). Apart from these competence

1 In the CHEERS project all courses were coded into the ISCED 2-digit classification.

2 In the case of the 1990/1991 cohort in the Netherlands this question relates to a rating of their competences at the time of the survey. 
items, we used a separate dummy to indicate the respondent's study or work experience abroad $(1=$ yes, $0=$ no) and we constructed dummies to indicate the length of relevant work experience during study and the length of internships ('work experience $>6$ months', 'work experience 1-6 months', 'internship > 6 months', 'internship 1-6 months'; all coded as $1=$ yes, $0=$ no with no work experience or no internship as the reference category). As almost none of the Japanese graduates have study-related work experience or have followed internships during their study, these dummies have only been constructed for the Dutch graduates of the 1994/1995 cohort (these questions have not been asked for the older Dutch cohort). Finally, we included age (in years) to pick up any remaining experience.

In model 5 we add the graduates' assessment of the quality of different aspects of the course taken in higher education. In the questionnaire the respondents were asked to rate the study conditions and study provisions. These items were grouped on theoretical grounds as follows: two items reflecting the quality of 'support' ('academic advice offered in general' and 'assistance/advice for your final examination'), five items relating to the quality of the 'content' ('course content of major', 'variety of courses offered', 'structure of undergraduate curriculum', 'teaching quality', 'research emphasis of teaching and learning'), two items relating to the quality of 'practical experience' ('chances to participate in research projects', 'provision of work placement and other work experience'), and three items reflecting the quality of 'study provisions' ('equipment and stocking of libraries', 'supply of teaching material', 'quality of technical equipment'). These four variables were simply calculated as the mean of the underlying items. Apart from these quality items, we also add two dummies referring to the 'use of the career office' or the 'use of teacher' to find a job after graduation. As graduates who got a job without actually searching did not respond to the question of search channels, we also include a dummy indicating a missing value on this question.

In model 6 we include ranking scores for the different universities and colleges. In the case of the Netherlands we used the Elsevier ratings mentioned above (Elsevier, 2001). These ratings are based on surveys among students, asking them to assess the quality of the course taken. In a way these ratings are quite comparable to the ratings in the CHEERS survey, taken up in model 5. The main advantage of using these additional scores is that they were gathered independently and are not biased by any subsequent labour market outcomes. Elsevier has published these ratings for the main university courses annually since 1999. For universities we took the ratings from 2000. For the courses in higher vocational education, a different set of courses is evaluated every year. 
Here we took the information from the surveys held in 1999-2001. ${ }^{3}$ In the Japanese case, ranking scores are based on the performance of the university on the entrance examination tests. Here we used the performance on the test about four years before graduation. As private universities use other tests than state and public universities, we add a dummy differentiating between these two types of universities ('private university'; $1=$ yes, $0=$ no).

\subsection{Results}

Table 4.1 displays the descriptive statistics of the variables in the analyses. As we can see, the wages earned by the Japanese graduates show on average more variance than the wages of the Dutch graduates. Furthermore, the wages in Japan seem to rise more steeply if we compare the old cohorts with the younger ones, but this difference is partly due to the fact that the Japanese old cohort is from 1988-1990 while the Dutch cohort is from 1990/1991. Thus they graduated on average 2-3 years before their Dutch colleagues.

There are some striking differences if we compare the educational sector from which the respondents graduated. In the Netherlands more respondents graduated from health sciences and business studies, while in Japan more respondents come from engineering, social sciences and law. The Dutch group of respondents is older on average, with a better gender-balance.

If we look at the self-rating of competences, we can conclude that Dutch graduates on average rate a higher possession of the different competences at the time of graduation than the Japanese graduates. We can only compare the youngest cohorts here, since the question for the 1990/1991 Dutch cohort refers to the possession of these competences at the time of the survey. As pointed out before, Dutch graduates have also studied or worked abroad more often during higher education, they have considerably more work experience related to the study, and they have more often followed an internship. In line with the differences in educational structure of both countries, we see that only about half of the Dutch graduates have followed the highest track in secondary education, while in Japan almost all graduates have followed the highest track. Note, however, that the secondary schools in Japan also have a strong hierarchical ordering that is not reflected in this variable.

3 Note that the evaluation rates in the Netherlands refer to the quality of the course a few years after the respondents left higher education. This quality may have changed in the meantime, which will affect the parameter of the quality scores. This time difference is also the reason why we did not use these ratings for the old cohort. However, if quality of a course is a relatively stable characteristic, and if this quality affects labour market outcomes, we should be able to find some effect on earnings. 
Table 4-1. Descriptive statistics: means, standard deviations and proportions

\begin{tabular}{|c|c|c|c|c|c|c|c|c|c|c|c|c|}
\hline \multirow[b]{2}{*}{ Variable } & \multicolumn{3}{|c|}{ JP $94 / 95$} & \multicolumn{3}{|c|}{ JP 88/90 } & \multicolumn{3}{|c|}{ NL 94/95 } & \multicolumn{3}{|c|}{ NL $90 / 91$} \\
\hline & mean & $\mathrm{Sd}$ & $\%$ & mean & $\mathrm{Sd}$ & $\%$ & mean & $\mathrm{Sd}$ & $\%$ & mean & $\mathrm{Sd}$ & $\%$ \\
\hline Ln (hourly wage) & 2.57 & 0.43 & & 3.00 & 0.40 & & 2.51 & 0.31 & & 2.72 & 0.33 & \\
\hline University (NL) & & & n.a. & & & n.a. & & & 40.7 & & & 43.3 \\
\hline \multicolumn{13}{|l|}{ Field of study } \\
\hline Arts \& Humanities & & & 26.4 & & & 23.0 & & & 16.8 & & & 24.4 \\
\hline Social Sciences & & & 16.9 & & & 16.1 & & & 9.7 & & & 10.2 \\
\hline Business Studies & & & 12.3 & & & 6.9 & & & 25.3 & & & 19.5 \\
\hline Law & & & 10.3 & & & 13.7 & & & 5.7 & & & 5.4 \\
\hline Natural Sciences & & & 6.7 & & & 8.6 & & & 7.3 & & & 7.4 \\
\hline Engineering & & & 20.6 & & & 24.3 & & & 16.6 & & & 13.1 \\
\hline Health Sciences & & & 6.7 & & & 7.3 & & & 18.7 & & & 20.0 \\
\hline \multicolumn{13}{|l|}{ Input Characteristics } \\
\hline $\begin{array}{l}\text { Acad. Sec. } \\
\text { Education }\end{array}$ & & & 95.1 & & & 95.3 & & & 55.1 & & & 61.0 \\
\hline Male & & & 57.0 & & & 72.1 & & & 45.3 & & & 51.5 \\
\hline $\begin{array}{l}\text { Father higher } \\
\text { education }\end{array}$ & & & n.a. & & & 35.9 & & & 36.3 & & & 33.2 \\
\hline $\begin{array}{l}\text { Mother higher } \\
\text { education }\end{array}$ & & & n.a. & & & 17.2 & & & 17.1 & & & 14.6 \\
\hline \multicolumn{13}{|l|}{ Competences" } \\
\hline $\begin{array}{l}\text { Cross-disciplin. } \\
\text { Thinking }\end{array}$ & 2.96 & 0.92 & & 2.93 & 0.92 & & 3.06 & 0.76 & & 3.31 & 0.80 & \\
\hline Foreign language & 2.53 & 1.05 & & 2.31 & 1.05 & & 3.25 & 0.94 & & 3.36 & 1.03 & \\
\hline Computer skills & 2.54 & 1.25 & & 2.09 & 1.18 & & 3.21 & 0.95 & & 3.57 & 1.01 & \\
\hline Applying rules & 2.87 & 1.00 & & 2.73 & 0.98 & & 3.02 & 0.97 & & 3.43 & 0.98 & \\
\hline $\begin{array}{l}\text { Economic } \\
\text { reasoning }\end{array}$ & 2.49 & 1.08 & & 2.22 & 1.03 & & 2.88 & 1.06 & & 3.20 & 1.06 & \\
\hline Problem solving & 3.17 & 0.89 & & 3.03 & 0.88 & & 3.72 & 0.78 & & 4.18 & 0.65 & \\
\hline $\begin{array}{l}\text { Analytical } \\
\text { competences }\end{array}$ & 3.22 & 0.90 & & 3.16 & 0.90 & & 3.62 & 0.85 & & 4.00 & 0.80 & \\
\hline Time management & 3.01 & 1.05 & & 2.86 & 1.03 & & 3.44 & 0.89 & & 3.74 & 0.88 & \\
\hline Negotiating & 2.49 & 1.02 & & 2.42 & 1.03 & & 2.83 & 0.94 & & 3.38 & 0.98 & \\
\hline Working in a team & 3.33 & 0.97 & & 3.18 & 0.98 & & 3.82 & 0.86 & & 4.20 & 0.73 & \\
\hline Concentration & 3.67 & 0.94 & & 3.67 & 0.93 & & 3.84 & 0.79 & & 3.87 & 0.82 & \\
\hline $\begin{array}{l}\text { Written conmunic. } \\
\text { Skills }\end{array}$ & 3.10 & 0.98 & & 3.09 & 0.97 & & 3.76 & 0.83 & & 3.98 & 0.80 & \\
\hline Leadership & 2.89 & 1.03 & & 2.83 & 1.01 & & 2.88 & 0.98 & & 3.50 & 0.94 & \\
\hline $\begin{array}{l}\text { Taking } \\
\text { responsibilities }\end{array}$ & 2.89 & 1.01 & & 2.83 & 0.98 & & 3.67 & 0.91 & & 4.30 & 0.70 & \\
\hline Loyalty & 3.89 & 0.87 & & 3.87 & 0.87 & & 3.89 & 0.85 & & 4.32 & 0.67 & \\
\hline Age at time survey & 27.25 & 0.99 & & 33.35 & 1.39 & & 28.94 & 2.40 & & 33.76 & 3.35 & \\
\hline Foreign experience & & & n.a. & & & n.a. & & & 30.7 & & & 28.2 \\
\hline
\end{tabular}




\begin{tabular}{|c|c|c|c|c|c|c|c|c|c|c|c|c|}
\hline \multirow[b]{2}{*}{ Variable } & \multicolumn{3}{|c|}{ JP $94 / 95$} & \multicolumn{3}{|c|}{ JP $88 / 90$} & \multicolumn{3}{|c|}{ NL $94 / 95$} & \multicolumn{3}{|c|}{ NL $90 / 91$} \\
\hline & mean & $\mathrm{Sd}$ & $\%$ & mean & $\mathrm{Sd}$ & $\%$ & mean & $\mathrm{Sd}$ & $\%$ & mean & $\mathrm{Sd}$ & $\%$ \\
\hline $\begin{array}{l}\text { Work experience } \\
1-6 \text { months }\end{array}$ & & & n.a. & & & n.a. & & & 14.7 & & & n.a. \\
\hline $\begin{array}{l}\text { Work experience > } \\
6 \text { months }\end{array}$ & & & n.a. & & & n.a. & & & 10.8 & & & n.a. \\
\hline $\begin{array}{l}\text { Internship 1-6 } \\
\text { months }\end{array}$ & & & n.a. & & & n.a. & & & 29.4 & & & n.a. \\
\hline $\begin{array}{l}\text { Internship > } \\
6 \text { months }\end{array}$ & & & n.a. & & & n.a. & & & 43.2 & & & n.a. \\
\hline Course characteristi & & & & & & & & & & & & \\
\hline Support & 3.53 & 0.83 & & 3.62 & 0.81 & & 2.88 & 0.72 & & n.a. & & \\
\hline Content & 3.12 & 0.65 & & 3.20 & 0.63 & & 3.33 & 0.54 & & n.a. & & \\
\hline $\begin{array}{l}\text { Practical } \\
\text { experience }\end{array}$ & 2.43 & 0.86 & & 2.39 & 0.86 & & 3.17 & 0.81 & & n.a. & & \\
\hline Provisions & 3.36 & 0.82 & & 3.28 & 0.80 & & 3.44 & 0.71 & & n.a. & & \\
\hline Use of career office & & & 53.1 & & & 38.0 & & & 8.7 & & & n.a. \\
\hline Use of teacher & & & 19.7 & & & 17.7 & & & 8.8 & & & n.a. \\
\hline $\begin{array}{l}\text { Missing on } \\
\text { office/teacher }\end{array}$ & & & 16.6 & & & 28.0 & & & 22.7 & & & n.a. \\
\hline University ranking & 56.39 & 5.28 & & 55.71 & 7.32 & & 6.72 & 0.26 & & n.a. & n.a. & \\
\hline $\begin{array}{l}\text { Private university } \\
\text { (JP) }\end{array}$ & & & 59.6 & & & 40.5 & & & n.a. & & & n.a. \\
\hline $\mathrm{N}$ individuals & & 2235 & & & 1452 & & & 2178 & & & 1595 & \\
\hline $\begin{array}{l}N \text { university-course } \\
\text { combinations }\end{array}$ & & 170 & & & 117 & & & 178 & & & 197 & \\
\hline $\mathrm{N}$ courses & & 14 & & & 19 & & & 34 & & & 39 & \\
\hline
\end{tabular}

${ }^{a}$ For the Dutch $190 / 91$ cohort these competences refer to the time of the survey rather than the time of graduation

If we look at quality aspects of the study, Japanese graduates not only have a more positive judgment about the support of their teachers during their study, but - as expected - they also made more use of career office or teachers to help finding a job. More than half of the Japanese graduates in the youngest cohort make use of the career office and about $20 \%$ enlisted the help of teachers to find a job. For the older cohort these percentages are somewhat lower, perhaps reflecting the better conditions when they entered the labour market. In the Netherlands fewer than $10 \%$ use either the career office or the help of teachers. On the other hand, Dutch graduates are more positive about the opportunities during their study to gain practical experience.

The question remains whether these course characteristics differ between universities and colleges. The underlying logic of taking them up in an 
explanatory analysis of university effects is based on the assumption that these course characteristics do differ between universities or colleges. In Table 4.2 we show the between-universities variance as a percentage of the total variance using ANOVA.

As we can see, the between-university variance is considerable in Japan. For most of the indicators the variance between universities amounts to some $10-20 \%$ of the total variance. This indicates that graduates of different universities have systematically different judgments about the quality of the courses they followed. Only in the case of the use of teachers as a search channel do we see few systematic differences between universities. This means that in most universities roughly the same percentage of graduates have made use of teachers to search for a job. In the Netherlands, graduates of the different universities and colleges do differ systematically in their evaluation of the quality of their study, but the differences are not as large as in Japan. This is in line with the high degree of standardisation in Dutch higher education.

Before presenting the parameter estimates of the variables in the different models, we first turn to the estimation of the between-university/college variance in the wage equations. This between-university/college variance can be seen as the effect of universities and colleges on the returns to education. Table 4.3 displays the residual variance components at the different levels for each of the estimated models. The residual variance is expressed as a percentage of the original total variance in the empty model (model 1).

As pointed out before, the total variance in ln (hourly wages) is larger in the two Japanese cohorts than in the Dutch cohorts. In all four cohorts, the largest part of the variance is between individuals within courses and colleges. However, this individual variance is largest in the youngest Japanese cohort and lowest in the two oldest cohorts. We can also conclude that the different models in question only partly explain the differences in wages. If we take model 6 as a final model, then only $14 \%$ of the wage is

Table 4-2. Between-institution variance in course characteristics

\begin{tabular}{lrrr}
\hline & JP 94/95 & JP 88/90 & NL 94/95 \\
\hline Course characteristics & & & $5.5^{* *}$ \\
Support & $8.4^{* *}$ & $9.3^{* *}$ & $9.7^{* *}$ \\
Content & $10.1^{* *}$ & $14.1^{* *}$ & $9.3^{* *}$ \\
Practical experience & $10.4^{* *}$ & $11.0^{* *}$ & $10.7^{* *}$ \\
Provisions & $15.2^{* *}$ & $23.1^{* *}$ & $7.3^{* *}$ \\
Use of career office & $18.3^{* *}$ & $13.9^{* *}$ & $5.7^{* *}$ \\
\hline
\end{tabular}

Not available for NL 90/91

${ }^{* *} \mathrm{p}<.01 ;{ }^{*} \mathrm{p}<.05$ 
Table 4-3. Residual variance components in the different models

\begin{tabular}{|c|c|c|c|c|c|c|}
\hline \multirow[b]{2}{*}{ Model } & \multicolumn{3}{|c|}{ JP 94/95 } & \multicolumn{3}{|c|}{$\mathrm{JP} 88 / 90$} \\
\hline & Level 1 & Level 2 & Level 3 & Level 1 & Level 2 & Level 3 \\
\hline Empty model (1) & $88.0^{* *}$ & $8.6^{* *}$ & 3.5 & $76.9 * *$ & $20.5^{* *}$ & 2.6 \\
\hline+ sector + university NL (2) & $88.0^{* *}$ & $8.7^{* *}$ & 0 & $77.2 * *$ & $19.2 * *$ & 0 \\
\hline + input characteristics (3) & $85.0^{* *}$ & $7.6^{* *}$ & 0 & $74.3^{* *}$ & $15.1 * *$ & 0 \\
\hline+ competences $(4)$ & $84.0^{* *}$ & $7.2 * *$ & 0 & $72.4 * *$ & $14.3 * *$ & 0 \\
\hline+ course characteristics (5) & $83.6^{* *}$ & $6.2 * *$ & 0 & $72.3^{* *}$ & $13.4^{* *}$ & 0 \\
\hline+ ranking scores $(6)$ & $84.0^{* *}$ & $2.5^{* *}$ & 0 & $72.7^{* *}$ & $5.0^{* *}$ & 0 \\
\hline \multirow[t]{2}{*}{ Total variance (model 1) } & \multicolumn{3}{|c|}{$\begin{array}{c}0.18249 \\
(=100 \%) \\
\end{array}$} & \multicolumn{3}{|c|}{$\begin{array}{c}0.18039 \\
(=100 \%) \\
\end{array}$} \\
\hline & \multicolumn{3}{|c|}{ NL 94/95 } & \multicolumn{3}{|c|}{ NL $90 / 91$} \\
\hline Model & Level 1 & Level 2 & Level 3 & Level 1 & Level 2 & Level 3 \\
\hline Empty model (1) & $83.7^{* *}$ & $6.2 * *$ & $10.1 * *$ & $78.3^{* *}$ & $10.9^{* *}$ & $10.8^{*}$ \\
\hline + sector + university NL (2) & $83.8^{* *}$ & $2.6^{*}$ & $6.2^{*}$ & $78.8^{* *}$ & $4.9 * *$ & 2.2 \\
\hline + input characteristics (3) & $82.8^{* *}$ & $2.5^{*}$ & $4.7^{*}$ & $77.1^{* *}$ & $4.4^{* *}$ & 1.4 \\
\hline+ competences $(4)$ & $78.7^{* *}$ & $2.2^{*}$ & $3.3^{*}$ & $69.9 * *$ & $3.0^{*}$ & 1.0 \\
\hline+ course characteristics $(5)$ & $\begin{array}{c}78.5^{* *} \\
\left(78.9^{* *}\right)^{\mathrm{a}}\end{array}$ & $\begin{array}{c}2.2^{*} \\
(2.7)^{\mathrm{a}}\end{array}$ & $\begin{array}{c}3.0^{*} \\
(4.5)^{\mathrm{a}}\end{array}$ & n.a. & n.a. & n.a. \\
\hline $\begin{array}{l}\text { + ranking scores }(6) \\
\text { Total variance (model } 1 \text { ) }\end{array}$ & $\left(78.9^{* *}\right)^{\mathrm{a}}$ & $\begin{array}{r}(2.7)^{\mathfrak{a}} \\
0.10007 \\
(=100 \%)\end{array}$ & $(4.5)^{\mathrm{a}}$ & n.a. & $\begin{array}{c}\text { n.a. } \\
0.10938 \\
(=100 \%)\end{array}$ & n.a. \\
\hline
\end{tabular}

Level $1=$ individuals; level $2=$ university-course combinations; level $3=$ courses

** $\mathrm{p}<.01 ; * \mathrm{p}<.05$

a estimated on a restricted data set for which ranking scores were available

explained in the 1994/95 Japanese cohort, 22\% in the 1988/90 Japanese cohort and $14 \%$ in the youngest Dutch cohort. The corresponding figure in model 4 for the oldest Dutch cohort is $26 \%$. We can also argue that we should only look at the residual variance at the individual level. The other variance components are determined by the specific course followed or university/college attended. In that case we can say that the model 'explains' $16 \%$ of the wage differences in the youngest Japanese cohort, $27 \%$ of the wage differences in the oldest Japanese cohort, $21 \%$ of the wage differences in the youngest Dutch cohort and $30 \%$ of the wage differences in the oldest Dutch cohort. In general, then, the models explain the wage differences rather well, with the exception of the youngest Japanese cohort. The models for the Dutch cohorts perform very well, considering the smaller wage variance in the Netherlands.

At the start of their career, three years after graduation, Japanese graduates already find themselves in different jobs with different rewards. About $9 \%$ of the wage differences are related to the specific university from which they graduated. For the older cohort, this university effect increases to $21 \%$ of the total variance. This may relate to career as well as to cohort effects. The cohort effect means that differences between universities (or rather, effects of universities) have diminished over time. 
Indications may be found in Table 4.1 showing that the variance in ranking scores is indeed smaller in the youngest cohort. Moreover, some Japanese firms have abolished the existing practice of asking graduates about the institute from which they graduated. This also points to decreasing effects of the signalling function of educational credentials. On the other hand, the result may also relate to career effects, meaning that the careers of graduates of the 'best' universities have a steeper profile than the careers of graduates of 'ordinary' universities. Considering the fact that job mobility is very low in Japan (as many as $70 \%$ of the graduates of the old cohort are still working in their first job), the career profiles typically reveal differences in firms' internal labour markets. Although the entry level may not differ much, the career prospects can differ greatly between firms. The data do not allow us to distinguish decisively between these two interpretations.

As expected, we find larger university effects on the returns to education in Japan than in the Netherlands. The university effect for the oldest Japanese cohort is twice as high as for the corresponding Dutch cohort. In the Netherlands differences between universities and colleges are largely explained by the differences in level and the specific educational sector of the course followed (see model 2). The between-university/college variance drops to 3\% if one controls for these variables in the youngest cohort and to $5 \%$ in the oldest cohort. Compared to the Japanese case this may not look very impressive, but the fact remains that these differences remain significant (albeit small) even after controlling for other variables in the model. Moreover, we observe that the oldest cohort shows larger university/college effects than the youngest one. Again, this result may be explained in two directions: differences between colleges and universities may have decreased over time, or the effect of the colleges and universities increase over the career. As was the case for Japan, the data do not allow us to favour one explanation over the other.

The introduction of input characteristics causes a significant drop in the residual variance at the university level in the oldest Japanese cohort from $19 \%$ in model 2 to $15 \%$ in model 3 . The decrease is much larger than for the other cohorts. The introduction of competence-related measures in model 4 reveals that both at the individual level and at the university level, wage differences in Japan are hardly related to any subjective rating of possession of competences. In the Netherlands these competence-related measures do explain some of the individual level variance, and some of the differences between universities or colleges in the oldest cohort. Model 5 shows some effect of the introduction of quality indicators, but the drop in residual variance at the university/college level is only $1 \%$ for the Japanese cohorts and zero for the young Dutch cohort. The differences between Japanese 
universities do seem to relate strongly to the prestige of universities, as model 6 shows. Introduction of the ranking scores and the difference between state/public and private universities causes a drop in the residual variance from $6 \%$ to $3 \%$ in the youngest cohort and from $13 \%$ to $5 \%$ in the oldest cohort. For the Dutch cohort, however, no effect of ranking can be found on university/college differences. As ranking scores were only available for about half of the college-course combinations, model 6 was estimated on a restricted dataset for the young Dutch cohort. For comparison, model 5 was estimated both on the total dataset and on the restricted dataset.

If we look at the course level, we can find only little systematic variance between the different courses in average earnings in the Japanese cohorts. After controlling for educational sector, these differences even disappear completely. This means that the specific course followed has little or no effect on future earnings. The situation is quite different for the Dutch cohorts. In the youngest cohort especially, the course followed has a profound effect on the returns. These course effects remain significant even after controlling for educational sector, level of higher education (university versus higher vocational education), individual input characteristics, acquired competences and quality indicators. The fact that these course differences are much smaller for the oldest Dutch cohort seems to suggest that the course effects relate to entry problems: the graduates of some courses face worse labour market conditions than others. They have to more or less 'fight' their way in. However, the long-term effects seem modest. After a period of 7 years most differences between courses have faded away (once we control for sector effects and level of higher education).

Let us now turn to the parameter estimates in the final models (Table 4.4). For the Japanese cohorts this refers to model 6. For the youngest Dutch cohort the estimates for most parameters are based on the full dataset and are taken from model 5. Only the estimate for ranking is based on the restricted dataset of model 6 . For the oldest Dutch cohort parameters are based on model 4. As indicated before, there is a large wage gap between Dutch graduates from universities or from colleges of higher vocational education. The wage premium for university graduates is $11 \%$ in the youngest cohort and $19 \%$ in the oldest cohort, indicating that university graduates also have steeper earning profiles. There are also differences in average earnings between the educational sectors. These are largest in the oldest Dutch cohort and the youngest Japanese cohort. In all cohorts graduates from Arts \& Humanities earn the least on average. High earnings in Japan are associated with Natural Sciences, Engineering and Health Sciences, while in the Netherlands the highest earnings are found among graduates from Business Studies and Law. 
Table 4-4. Three-level analysis on In (hourly wages) (only significant effects are shown)

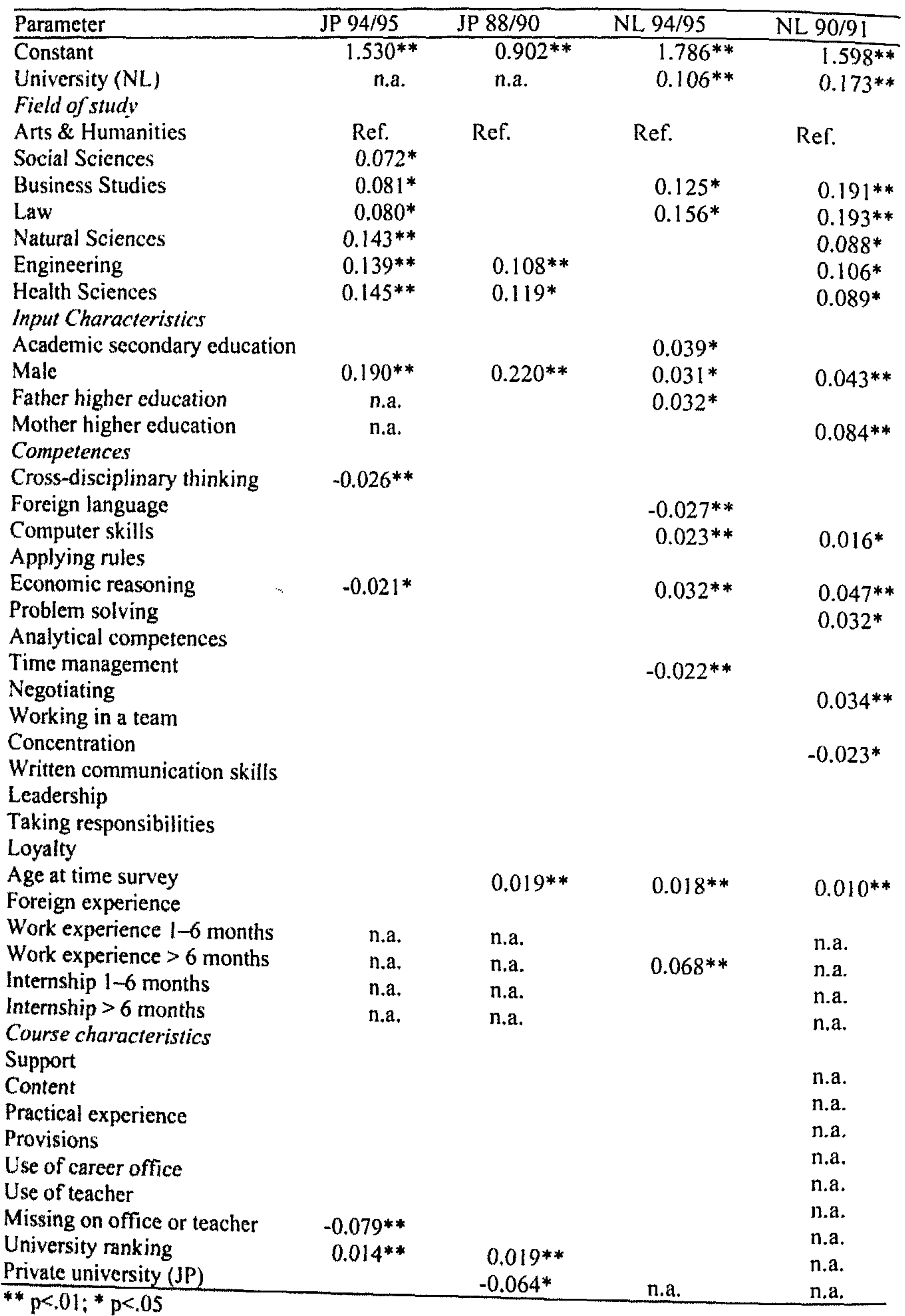


Both Japanese cohorts show a large gender gap in hourly wages. Controlling for other variables, Japanese men earn on average $21 \%$ (young cohort) to $25 \%$ (old cohort) more than women. The gender difference in the Netherlands is much smaller: 3 and 4\% respectively. Social background only has an effect for the Dutch cohorts: in the oldest cohort the wage premium for having a mother who followed higher education is $9 \%$ and graduates from the youngest cohort receive a wage premium if their father has followed higher education (increase 3\%). The absence of any direct social background effect in Japan is in line with the concept of a stronger meritocratic society. For the Dutch cohorts we also find a wage premium for having followed the highest track in secondary education: even after controlling for the level and sector taken in higher education, the previous level of secondary education still determines the wages of graduates to some extent. This could be a signalling effect, because the effect is only present for those who just made the transition to the labour market. The effect has faded away for the oldest cohort.

Interestingly enough, acquired competences during higher education show no effect (whatsoever) on the wages of Japanese graduates. Even taking into account the fact that we have used self-reports on the possession of these skills (which considerably reduces the reliability of the instrument), we nevertheless would have expected some effect, as indeed we have found for the Dutch cohorts. Instead we found two negative (!) effects of 'cross-disciplinary thinking' and 'economic reasoning' in the case of the youngest Japanese cohort and no significant effects at all for the oldest cohort. For the Dutch cohorts we find positive wage effects for 'computer skills', 'economic reasoning' and - only for the old cohort 'problem solving' and 'negotiating'. Negative effects are found for 'foreign language' and 'time management' (both in the young cohort) and 'concentration' (in the old cohort). As was more or less expected, we also find a positive effect of having study-related work experience, but only if it totals more than 6 months. Shorter periods of work experience or internships have no effect at all. This is not surprising, because the length of internships is usually determined in the curriculum and does not differentiate between graduates of the same course.

Age has an effect on earnings except for the graduates of the youngest Japanese cohort. This is due to the fact that Japanese graduates in general have no labour market experience before leaving higher education. The youngest cohort does therefore not differ in experience at the time of the survey. Things are different for the oldest Japanese cohort, because the

4 The opposite effects of 'economic reasoning' in the Japanese and Dutch cohorts are in line with the higher wage premium for graduates of Business Studies in the Netherlands. 
sample here includes graduates from two different years (1988/89 and 1989/1990).

There are no effects from the graduates' rating of the study conditions or the study provisions on the wages. This seems rather odd, considering the fact that universities and colleges - especially in Japan - do differ systematically in the graduates' rating of the quality indicators. Apparently, these graduates' evaluations do not relate in any way to their career prospects: graduates of universities and colleges that were rated as good have just the same career prospects as graduates from universities and colleges that received a low rating from their graduates.

No significant effects are found for enlisting the help of teaching staff or the career office to find a job. This implies that the best job offers are not necessarily allocated through the network of teachers, but might well go to graduates directly. The negative effect of the dummy 'missing value on office or teacher' indicates that graduates who found a job without actually searching for it ended up in low-paid rather than well-paid jobs.

Finally, we find significant effects of university ranking scores on the returns to education for both Japanese cohorts (and no effect at all for the Dutch cohort). The wage premium for a standard deviation increase in the average entry examination score is $7 \%$ for the young cohort and $14 \%$ for the old cohort. Apart from this there is an additional wage effect from having studied at a state or public university. The wage difference compared to private universities is $6 \%$ in favour of the state and public universities in the case of the oldest Japanese cohort. For the youngest cohort we find no significant effect of having graduated at a private university. Again, the effects may be explained as cohort effects, meaning that the differences between universities diminish over time, or as career effects, indicating that the university differences increase over the career.

\subsection{Conclusions}

In recent decades the assessment of the quality of higher education has become increasingly popular in most western countries. This growing interest in the public reporting and accountability of education is due to the following factors (Bosker et al., 2001; Dijkstra et al., 2001; Brennan et al., 1992):

5 Inclusion of a cross-level interaction between 'use of career office' and 'use of teacher' with the university ranking scores yielded the same, non-significant results. This means that enlisting the help of teaching staff or career office is not more effective in prestigious universities than in non-prestigious universities. 
- A growing awareness that improvement in the quality of education is necessary to increase the competitiveness on a global market and to face the, often uncertain, challenges of the future.

- Constraints on educational budgets due to higher enrolments, forcing the institutes of education to perform more effectively and efficiently.

- Increasing demands from the consumers (students) to be informed about the quality of educational institutes.

In this chapter we have analyzed the differences between universities and colleges in the returns to education. As expected, we found large effects on the earnings of Japanese graduates as a result of the university attended, and only small differences between universities and colleges in the Netherlands, once we control for the difference in level of higher education. Apart from the dual structure, with universities on the one hand and colleges of higher vocational education on the other hand, Dutch higher education is highly standardised, with relatively small differences in quality. Still, the effect of the university or college attended is also significant in the Netherlands, and the results are in line with previous results showing small differences between universities or colleges of higher vocational education on labour market outcomes (Bosker et al., 2001; Allen et al. 2000). Interestingly, these differences are neither related to the quality ranking scores as published by Elsevier nor to the quality assessment by the graduates themselves. For the oldest Dutch cohort we have found some evidence that university and college differences are related to a differential accumulation of competences and some differential selection. However, the effects are not very large and they are not replicated in the youngest cohort.

This is quite different from the results found in Japan. The university that graduates attended has a powerful effect on their future earnings and career prospects. Surprisingly, these differences are neither related to differences in acquired competences nor to differences in the graduates' assessment of the quality of the course taken, but are a direct function of the prestige of the university/college or of the student composition. Stated differently, coming from one of the prestigious universities affords the graduates access to better paid jobs, and - even more important - to better career prospects. The analysis seems to indicate that this prestige is not related to simple indicators of quality, differences in the kind of competences that can be acquired, nor to the social network of the teachers. Instead, the prestige of the university serves primarily as a signal of the graduates' future productivity. The Japanese educational system is strongly oriented towards a one-dimensional ranking of students during their whole school-career. The best students are selected into the most prestigious schools for secondary education and in turn these schools offer the best preparation to enter the most prestigious 
universities. Japanese employers use this ranking of universities to select students for the best jobs. The best job offers go to male students from the most prestigious universities. The specific course taken or the specific competences of the graduates have no effect at all, mainly because jobrelated skills are taught on the job.

Specific competences do have an impact on the wages of Dutch graduates. Especially during the transition phase, the specific course followed has a profound effect on earnings. After 7 years of labour market experience, these course effects decrease strongly. But wages are also related to other competence-related indicators, such as work experience and competences possessed at the time of graduation. This means that the selection process by Dutch employers is more focused on specific competences, while the selection process by Japanese employers is more focused on the prestige of the university attended as an indicator of future trainability.

The results also underline another characteristic of the Japanese educational system, namely the strong sense of giving support to students. This is not only reflected in the fact that Japanese students are more positive about the amount of support they received during their study, but is most evident in the important role of career offices and teachers in helping students to find a job. The fact that use of the career office has no effect on future earnings simply means that all kinds of students make use of this search channel and that all kinds of jobs are passed through this channel. The elaborate structure of career and placement offices in Japan is generally regarded as one of the key factors underlying the smooth transition from school to work in Japan (OECD, 2000). The support that Japanese education offers to their students is like a tightly woven safety net. In the Netherlands, on the other hand, this kind of support is often absent. The stronger individualistic orientation of the Dutch society therefore results in greater difficulties in finding a job (Allen et al., 2000).

\section{References}

Allen, J.P., Ramaekers G.W.M., Verbeek, A.E. (2000), WO-Monitor 1999. De arbeidsmarktpositie van afgestudeerden van de Nederlandse universiteiten, VSNU, Utrecht.

Alwin, D.F. (1974), College effects on educational and occupational attainment, Americain Sociological Review, 39, pp. 210-223.

Bosker, J., R. van der Velden, P. van de Loo (2001), Assessing institutional effects of colleges. The labour market success of their graduates, in: L.F.M. Nieuwenhuis, W.J. Nijhof (eds.), The Dynamics of VET and HRD Systems, Twente University Press, Enschede.

Brennan, J., L.C.J. Goedegebuure, T. Shah, D.F. Westerheijden, P.J.M. Weusthof (1992), Towards a methodology for comparative quality assessment in European higher education, a pilot study in Germany, the Netherlands and the United Kingdom, Council for National 
Academic Awards, London, Center for Higher Education Policy Studies, Enschede, Hochschul-Informations-System, Hannover.

Bryk, A.S., S.W. Raudenbusch (1992), Hierarchical linear models, Sage, Newbury Park.

Card, D., A. Krueger (1992), Does school quality matter? Returns to education and the characteristics of public schools in the United States, Journal of Political Economy, 100, pp. $1-40$.

Card, D., A. Krueger (1996), Labor market effects of school quality: theory and evidence, working paper no. 357, Princeton University.

Creemers, B.P.M., J. Scheerens (1994), Developments in the educational effectiveness Research programme, International Journal of Educational Research, 21, pp. 123-140.

Dijkstra, A.B., S. Karsten, R. Veenstra, A.J. Visscher (2001), Het oog der natie: scholen op rapport. Standaarden voor de publicatie van schoolprestaties, Koninklijke Van Gorcum, Assen.

Elsevier (2001), De beste hogescholen en universiteiten, Speciale uitgave oktober 2001. Elsevier, Amsterdam.

Goldstein, H. (1995), Multilevel statistical models, Edward Arnold, London.

Ishida, H., Spilerman, S., Su, K-H. (1997), Educational credentials and promotion chances in Japanese and American organisations, American Sociological Review, 62, pp. 866-882.

Johnson, G., F. Stafford (1973), Social returns to quantity and quality of schooling, Journal of Human Resources, 8, pp. 139-155.

Morgan, J., I. Sirageldin (1968), A note on the quality dimension in education, Journal of political economy, 76, pp.1069-1077.

Psacharopoulos (1979), On the weak versus strong version of the screening hypothesis, Economic Letters, 4, 181-185.

Rosenbaum, J.E., T. Kariya, R. Settersten, T. Maier (1990), Market and network theories of the transition from high school to work. Their application to industrialized societies, Annual Review of Sociology, 16, pp. 263-299.

Rumberger, R.W., Thomas, S.L. (1993), The economic returns to college major, quality and performance. A multi-level analysis of recent graduates, Economics of Education Review, 12,1, pp. 1-19.

Sakamoto, A., Powers, D. (1995), Education and the dual labor market for Japanese men, American Sociological Review, 60, pp. 222-246.

Scheerens, J., R.J. Bosker (1997), The foundations of educational effectiveness. Pergamon, Oxford.

Snijders, T.A.B. , Bosker, R.J. (1999), Multilevel analysis. An introduction to basis and advanced multilevel modeling. Sage Publications Ltd. London.

Trusheim, D., Crouse, J. (1981), Effects of college prestige on mens' occupational status and income, Research in Higher Education, 14, pp. 283-304.

Wachtel, P. (1976), The effects on earnings of school and college investment expenditures, Review of Economics and Statistics, 58, pp. 326-331.

Webster, T.J. (2001), A principal component analysis of the US News \& World Report tier rankings of colleges and universities; Economics of Education Review, 20, 3, pp. 235-244.

Welch, F. (1966), Measurement of the quality of education, American Economic Review, 56, pp. 379-392.

Wise, D.A. (1975), Academic achievement and job performances, American Economic Review, 65, pp. 350-366. 